\title{
Vastuu ja huolenpito elämänkulussa
}

\section{- transaktioanalyysi ja biografia perheenjäsenten välisten suhteiden muutoksen välineinä}

\author{
ILSE ERIKSSON
}

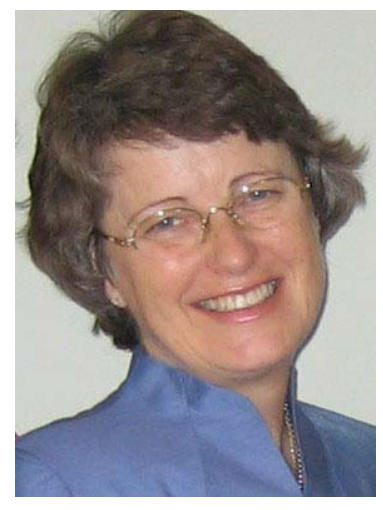

Jokainen perheenjäsen vaikuttaa perheen ihmissuhteisiin ja niiden toimivuuteen lapsuudesta asti. Kaikilla perheenjäsenillä on vastavuoroinen vastuu perheen toiminnasta. Kaikkien vastuun- periaate ei kuitenkaan ohita lapsen oikeutta tulla vanhempiensa suojelemaksi ja hoivaamaksi. Artikkeli käsittelee perheenjäsenten välisiä elinikäisiä vuorovaikutussuhteita ja mahdollisuuksia kehittää niitä.
$\mathrm{T}$ ulevina vuosikymmeninä perheeseen liittyvät vastuukysymykset tulevat uudella tavalla ajankohtaisiksi, kun pohditaan, miten huolehditaan vanhusväestöstä. Yli 65-vuotiaiden osuus väestöstä kasvaa Suomessa ennusteen mukaan noin 17 prosentista vuonna 2010 vähitellen 26 prosenttiin vuonna 2030. (Tilastokeskus 2007). Tulee pohtia, miten vastuu vanhuksista jaetaan lasten ja yhteiskunnallisten instituutioiden kesken ja millaisilla yhteiskuntapoliittisilla päätöksillä perheenjäsenten välistä huolenpitoa tuetaan. (ks. Kansallinen sosiaalialan kehittämisraportti 2003; Killian \& Ganong 2002). Vaikka yhteiskunnalliset ratkaisut ovatkin merkittävät, myös perheen sisäiset suhteet vaikuttavat siihen, miten perheenjäsenistä huolehditaan.

Artikkelini tavoitteena on esitellä työvälineitä perheenjäsenten välisten suhteiden kehittämiseen. Esimerkkien avulla teen näkyväksi 1) miten biografista työskentelyä voi käyttää edistämään perheenjäsenten suhteiden kehittymistä, sekä 2) miten transaktioanalyysin avulla voidaan tehdä näkyväksi vuorovaikutukseen liittyviä ongelmakohtia.

Perheenjäsenten väliset suhteet eivät aina tue vastavuoroisen huolenpidon kehittymistä. Eivät ainoastaan lasten suhteet vanhempiinsa ole keskeisiä hoitovastuuta ajateltaessa, vaan myös sisarusten väliset suhteet, kun hoitovastuuta jaetaan tasapuolisesti.

Artikkelin lähtökohta perheenjäsenten välisiin suhteisiin on transaktionaalinen. Sen mukaan jokainen perheenjäsen vaikuttaa perheen ihmissuhteisiin ja niiden toimivuuteen lapsuudesta asti. Kaikilla perheenjäsenillä on vastavuoroinen vastuu perheen toiminnasta. 'Kaikkien vastuun- periaate' ei kuitenkaan ohita lapsen oikeutta tulla vanhempiensa suojelemaksi ja hoivaamaksi. Lapsen oikeus on kirjattu lakiin ${ }^{1}$. Mainittu periaate ei myöskään ohita heikentyneiden vanhempien oikeutta tulla lastensa hoivaamiksi. Tämä oikeus ei kuitenkaan ole lainsäädännöllinen, sillä Suomessa täysi-ikäiset lapset eivät ole vastuussa vanhempien hoivasta ja huolenpidosta (Kansallinen sosiaalialan kehittämisprojekti 2003).

Sosiaalisen kanssakäymisen tai vuorovaikutuksen yksikköä kutsutaan transaktioksi (Berne 1964). Välineitä transaktioiden tarkasteluun antaa transaktioanalyysi, jota tässä artikkelissa tarkastelen perheen jäsenten suhteiden näkökulmasta ${ }^{2}$. 
Tarkastelen, miten vuorovaikutuksen muuttaminen aiempaa myönteisemmäksi voisi mahdollistua transaktioanalyysin minän analyysilla ja transaktioiden muodon tarkastelun avulla.

Artikkelin toinen lähtökohta perheen ihmissuhteiden muuttamiseen on omaelämäkerrallinen eli biografinen. Elämän kulussa omaa elämää tarkastellaan takautuvasti, jolloin elettyä elämää peilataan tämän hetkisiin kokemuksiin, tietoihin ja kypsyyteen. Tarkastellaan elettyä elämää, elämän ratkaisuja ja tulkintoja. Biografisella työskentelyllä tarkoitan sitä, että tarkastelen toistuvasti elämän eri jaksoja (lapsuus - nuoruus - varhaisaikuisuus - keski-ikä - vanhuus). Perheen elinikäisten ihmissuhteiden biografinen tarkastelu voi lisätä oman vastuun ymmärtämistä ja muiden perheenjäsenten tekojen kokonaisvaltaista näkemistä. Nämä lähestymistavat - biografinen ja transaktioanalyyttinen - täydentävät toisiaan perheen ihmissuhteiden tarkastelussa.

Tämä artikkeli keskittyy perheenjäsenten välisiin elinikäisiin vuorovaikutus-suhteisiin ja mahdollisuuksiin kehittää näitä suhteita. Tavoitteena on autonomisesti toimivien perheenjäsenten kehittyminen.

Käytän artikkelissa esimerkkejä erään 80-vuotiaan naisen biografisesta haastattelusta ${ }^{3}$. Valitsin hänet, koska hän oli halukas moneen kertaan puhumaan elämästään. Näitä haastatteluja tein vuoden aikana 16 kertaa. Biografisen kerrontaprosessin ymmärtämiseksi tällainen aineisto on merkittävä. Tästä haastattelu- aineistosta poimin kertojan kuvauksia perhesuhteistaan. Valitsin esimerkkejä lapsuudesta, nuoruudesta, aikuisuudesta ja vanhuudesta eli koko elämänkulusta. Näitä kuvauksia käytän artikkelissa esimerkkeinä valaisemaan tekstin näkökulmia.

\section{Biografia perheenjäsenten välisten suhteiden kuvaajana}

Biografista kuvausta elämästä tarkastelen tässä siitä näkökulmasta, että todellinen elämä eroaa kuvastusta elämästä. Jokainen antaa merkityksiä ja tulkintoja oman elämänsä tapahtumille ja ihmissuhteille itselleen tyypillisellä tavalla. Myös perheen ihmissuhteet tulevat biografiassa kuvatuiksi omien intentioiden ja tulkintojen kautta.

Jokainen luo biografisen kuvauksen elämästään riippumatta siitä, kertooko hän biografiaansa muille vai ei. Biografiassa kukin elämässä vaikuttanut henkilö saa paikan kerrontahetken merkityksen mukaan. Näin ollen myös perheen merkitys muuttuu biografisessa tarkastelussa. Merkitys määrittyy sen kokemuksen mukaan, mikä perheenjäsenillä on elämässä kerrontahetkellä. (ks. Eriksson-Stjernberg 1998, 70-73).

Lapsuuden lämpimät ihmissuhteet sisarusten välillä himmenevät biografiasta, jos kerrontahetken suhteet tai muistot näistä suhteista ovat huonot:

Hän oli hirveä tyyppi - veljeni...

Haastattelija: Piditkö yhteyttä veljeesi hänen viimeisenä elinvuonaan?

En tiedä miten hän kuoli ja missä hän kuoli. Kuoliko hän kotona vai sairaalassa. En minä tiedä....

Haastattelija: Kun hän oli kuollut miltä tuntui kun olitte tavallaan eronneet epäsovussa?

Ei miltään. Oli vain hyvä että ei tarvinnut tavata häntä kadulla.

Myönteisiä muistoja on vaikeata saada esille biografisessa kerronnassa, kun elämäntulkinta on kerrontahetkellä negatiivinen.

Haastattelija: Kerro mukavia muistoja, mukavia muistoja elämästäsi

Minulla ei ole mukavia muistikuvia. En minä muista.

Biografisen työskentelyn avulla, jossa toistuvasti tarkastellaan elämän eri jaksoja (lapsuus - nuoruus - varhaisaikuisuus - keski-ikä - vanhuus), voi aktiivisesti muuttaa nykyhetken tulkintoja (ks. Jones 2006, 219), kun koko elämänkulku tulee tasapuolisemmin esille.

Toistuvien elämän tarkastelujen jälkeen mukavat lapsuusmuistot tulevat esille:

Olimme aina olleet hyvin hyviä ystäviä veljeni kanssa kasvuvuosina. Kesäisin oli hienoa, kun mentiin moottoriveneellä saariin. Otettiin ruokaa mukaan ja uitiin kristallinkirkkaassa vedessä... Se oli ihanaa. Olin veljeni kanssa. Lähdimme aina yhdessä.

Omien muistojen sävy voi muuttua, jolloin oman elämänkulun kokemuskin voi muuttua aiempaa myönteisemmäksi. Tällöin myös suhtautuminen perheenjäseniin voi kehittyä aiempaa paremmaksi.

Perheessä vastavuoroisen huolenpidon kehittymisen keskeisinä elementteinä voidaan myös pitää perheenjäsenten kykyä muuttua suhteissaan toisiinsa. Tätä kykyä muuttaa omaa roolia suhteessa muihin perheenjäseniin ei välttämättä ole: 
Äitiä kuvasi vielä, että kun äiti makasi kuolinvuoteellaan sairaalassa. Hän sanoi minulle yhtäkkiä: "Muista että aina tottelet minua”.

Muuttuminen edellyttää jatkuvaa neuvottelua itsen ja perheenjäsenten kanssa. Perheen ihmissuhteet tarvitsevat vahvoina pysyäkseen toistuvia perherituaaleja ja merkitysten rakentamisia yhteisten tapaamisten ja sukupolvien sisäisten ja välisten biografisten kertomusten avulla. (ks. King \& Wynne 2004, 9). Joskus kuitenkin suhteita perheen sisällä ratkaistaan eristämällä joku henkilö perheen muista ihmisistä, jolloin estetään yhteisyyden rakentumista:

Sanoin äidille, että tähän kotiin ei tule enää kukaan ilkeä perheestämme. Minä otan sinut luokseni asumaan, mutta sinun tulee luvata, että isä ei astu jalallaan tähän taloon, eikä myöskään veljeni. Kukaan ei tule tänne, tämä on rauhoitettu.

Läpi elämän työstämme biografiassa suhteitamme lapsuudenaikaiseen perheeseemme. Ohessa on esimerkki keski-iässä tapahtuneesta perhesuhteiden työstämisestä:

Nuorin sisareni kirjoitti äidille ja kysyi: "Oletko oikeastaan koskaan rakastanut ketään?" ...Äiti sanoi, että sisar oli kysymyksessään aivan oikeassa. "En ole pitänyt oikein paljon kenestäkään."

Perheenjäseniin kohdistuvia määrittelyjä voidaan kuitenkin aktiivisesti muuttaa aktiivisen biografia työskentelyn avulla. Lisäksi transaktioanalyysin avulla voi haastaa perheenjäseniä ajattelemaan toisistaan aiempaa myönteisemmin (James, J. 1977, 357; James 1977, 3-6)

\section{Transaktioanalyysin minän tilat ja tran- saktion muodot}

Transaktioanalyysissa (Berne 1964; James 1977) yksilöä tarkastellaan kolmen minän tilan avulla eli Lapsen, Aikuisen ja Vanhemman. Kaikilla - myös lapsilla - on Aikuisen ja Vanhemman minän tila ja aikuisilla on myös Lapsen minän tila.

Intuitio, emootiot, luovuus ja nautiskelu ovat ominaisia Lapsen minän tilalle. Sille on ominaista myös kiukuttelu, vaativuus (anna minulle), nauraminen, kiusoittelu, ilo ja tarvitsevuus. Lapsen minän tilassa puolustaudutaan, ollaan vihamielisiä, hämmentyneitä, vetäytyviä tai toivottomia. Näiden lisäksi Lapsen minän tila liittyy läheisyyteen ja hellyyteen. (Berne 1964)

Aikuisen minän tilalle on ominaista suorien kysymysten esittäminen, suorien vastausten antaminen, tietojen käsitteleminen, tehokas työskentely, rohkeus, luotettavuus. Tätä minän tilaa voi luonnehtia realistiseksi (Berne 1981, 23). Myös vastuu muista ja itsestä on keskeistä. Kerätään tietoja, analysoidaan niitä ja tehdään päätöksiä järkevästi tosiasioihin pohjautuen. Aikuisen minän tilassa myös tarkastellaan omia Vanhemman ja Lapsen minän tiloja ja tullaan tietoisiksi näistä tiloista ja ohjataan näitä. Autonomiset henkilöt, eli Aikuisen minän tilan ohjaamat henkilöt, toimivat joustavasti kaikista minän tiloista. (James 1977, 65)

Vanhemman minän tilalle on ominaista, että siinä siirretään aiempien polvien traditioita ja arvoja lähes automaattisesti. Toisin sanoen on kyse vanhempien jäljittelystä (Berne 1981, 23). Kommunikaatiolle on tällöin usein ominaista ilmaisut "sinun pitää". Henkilö puhuu, toimii ja tuntee samoin kuin hänen omat vanhempansa - olipa sitten kyseessä tuomitsevuus, ennakkoluuloisuus, huolenpito, välinpitämättömyys tai apaattisuus. (Berne 1964, 23-27; James 1977, 509; James 1977, 53, 58).

Transaktioanalyysin tavoitteena on se, että ihmiset oppivat toimimaan autonomisina yksilöinä eivätkä vanhempiensa kopioina:

Ei hänellä (äidillä) myöskään ollut mitään hyvää suhdetta omaan äitiinsä...Mutta isoäiti oli samanlainen kuin äiti - ei häntä päässyt lähelle. Ei päässyt.

Tässä esimerkissä äidin kuvataan toistavan oman vanhempansa mallia eli toimivan reflektoimattomassa Vanhemman minän tilassa. Jokainen toimii näissä mainituissa kolmessa egon tilassa, mutta keskeiseksi muodostuu, millaisiksi vuorovaikutussuhteet eli transaktiot muodostuvat.

Aikuisen minän tilan kerrontaa voi nähdä seuraavassa esimerkissä:

Olen aikuisena ymmärtänyt, että isä painosti häntä (äitiä), mutta koska hän ei koskaan kertonut mitään - mitään ei koskaan selitetty, mutta silloin en ymmärtänyt.... Silloin ajattelin, että hän ei ole minun äitini, hän ei ollenkaan välitä meistä...

Äidin elämäntilannetta tarkastellaan realistisesti eikä vain Lapsen pettyneestä tilanteesta ja ymmärretään asioita laajemmissa yhteyksissään eli Aikuisen minän tilassa.

Transaktion muoto kuvaa, missä minän tilassa itse ollaan transaktiossa ja missä minän tilassa 
vuorovaikutuksen toinen osapuoli toimii. Transaktio muodostuu stimulus siirrosta (vuorovaikutuksen lähettäjä) ja siihen saadusta vastaussiirrosta (vuorovaikutuksen toinen osapuoli). Stimulus ja siihen saatu reaktio voidaan luokitella täydentyväksi tai risteytyväksi (James 1977, 12-14).

Täydentyvä transaktio muodostuu, kun ihmiset reagoivat avoimesti ja suoraan mistä tahansa minän tilasta ja saavat siihen reaktion, joka on odotettu ja tilanteeseen sopiva. Tällöin stimuluksen ja reaktion väliset kuvaukset ovat rinnakkaisia suoria (ks. kuviot 1 ja 2). Vuorovaikutus määritetään tarkoituksenmukaiseksi, mikäli vuorovaikutuksen lähettäjä ja vastapuoli toimivat toinen toisiaan täydentävästi. Täydentyviä transaktioita ovat Aikuinen - Aikuinen, Vanhempi - Vanhempi ja Lapsi - Lapsi. Näissä transaktioissa on kyse psykologisesti samanarvoisissa minän tiloissa toimivien kommunikaatiosta (ks. kuvio 1).

Kun vuorovaikutus on luonteeltaan täydentyvää, kommunikaatio jatkuu luontevasti. Keskus-
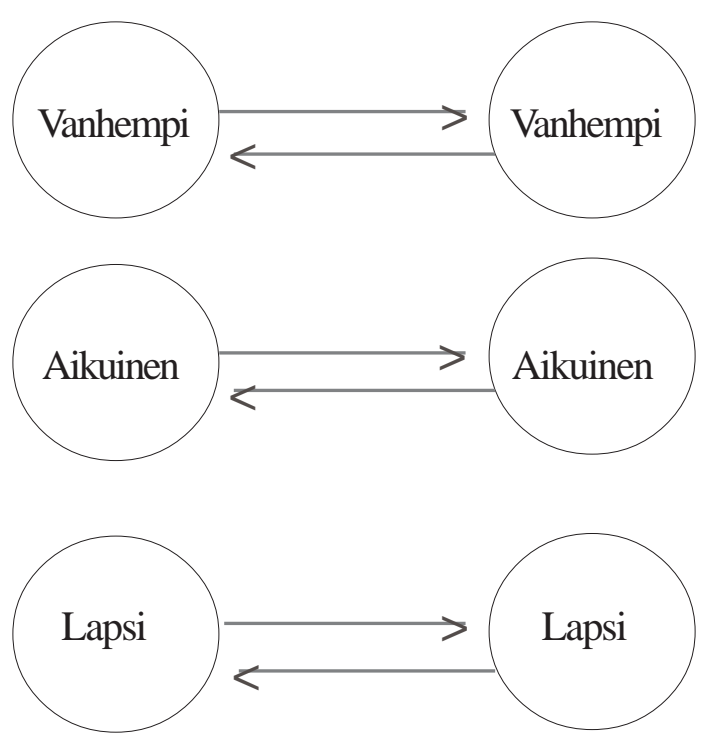

Kuvio 1. Psykologisesti samanarvoisissa minän tiloissa toimivien henkilöiden täydentyvä kommunikaatio (ks. Berne 1981, 29-32)

telu jatkuu molemminpuolisessa ymmärryksessä, olipa sitten kyse huolenpidosta (Vanhempi Vanhempi), yhteisestä pilailusta ja hassuttelusta (Lapsi - Lapsi) tai yhteisestä ongelmanratkaisusta (Aikuinen - Aikuinen) (Berne 1981, 29).

Psykologisesti samanarvoisissa minän tiloissa toimivien henkilöiden täydentyvän kommunikaa- tion lisäksi on myös psykologisesti eriarvoisissa minän tiloissa toimivien täydentyvää kommunikaatiota. Kuviossa 2 esitetään muut täydentyvän kommunikaation muodot (Berne 1981, 31).

Risteytyvästä transaktiosta (kuvio 3) on kyse, kun mistä tahansa minän tilasta lähetettyyn ärsykkeeseen vastataan kohtaamattomasti. Tällöin

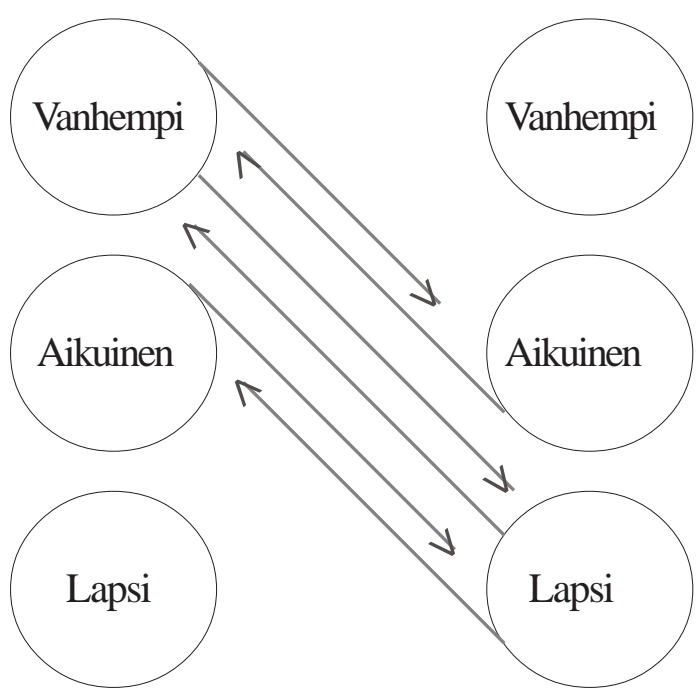

Kuvio 2. Psykologisesti eriarvoisissa minän tiloissa toimivien henkilöiden välinen täydentyvä kommunikaatio (ks. Berne 1981, 29-32)

vektorikuvaukset risteytyvät. Esimerkiksi kun Aikuisen minän tilasta lähetetään ärsyke ”Milloin tulet käymään?” ja siihen saadaan vastaus Vanhemman minän tilasta Lapsen minän tilaan ”Älä sinä siitä huolehdi”, tällöin kommunikaatio on kohtaamatonta. Sopiva eli täydentyvä vastaus olisi ollut Aikuisen minän tilasta lähetetty vastaus Aikuisen minän tilaan, jolloin olisi kerrottu, milloin tullaan.

Täydentyvissä transaktioissa kommunikaatio voi jatkua kuinka pitkään hyvänsä. Sen sijaan kun transaktiot ovat risteytyviä - kommunikaatio katkeaa. Kommunikaation osapuolet eivät tällöin koe olevansa samalla aaltopituudella toistensa kanssa. Tällaisia risteytyviä transaktioita ovat muut kuin kuvioissa 1 ja 2 esitetyt transaktiot. Kuviossa 3 esitetään selkeyden vuoksi vain yksi esimerkki risteytyvästä transaktiosta.

Jos ärsyketilanne on Aikuinen - Aikuinen, mutta vastaaja reagoi joko Lapsen tai Vanhemman (kuten kuviossa 3) minän tilasta silloin vuorovaikutuksen kuvaajat menevät ristiin ja puhutaan 


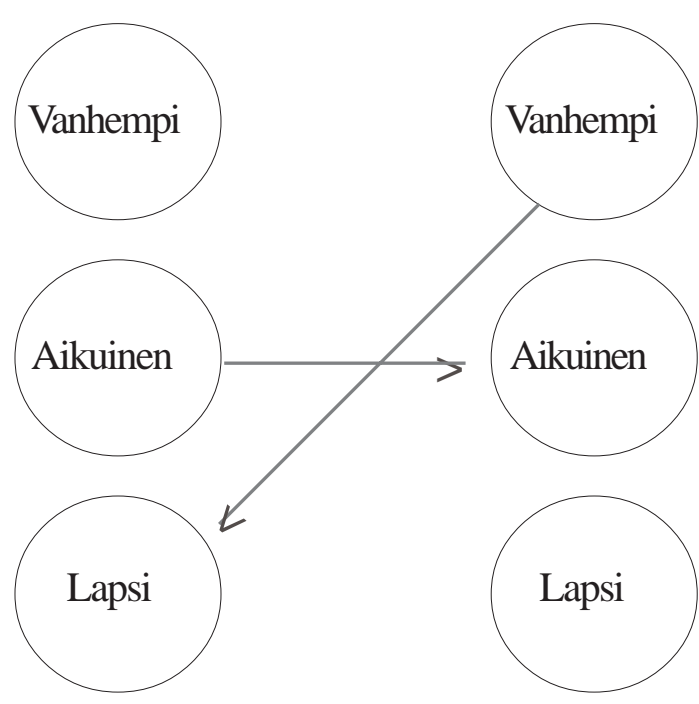

Kuvio 3. Esimerkki risteytyvästä transaktiosta (ks. Berne 1981, 31)

risteytyvästä kommunikaatiosta.

Kommunikaatio risteytyy myös silloin, kun ärsyketilanne on Lapsi - Vanhempi ja reaktio Lapsi - Lapsi, jolloin kommunikaatio katkeaa:

...istuin lattialle ja aioin kertoa äidille (koetusta epäoikeudenmukaisesta kohtelusta) että en ollut tehnyt mitään pahaa ja sitten isä antaa selkään. Ja äiti sanoo minulle, että asia ei kuulu hänelle. Mene matkoihisi. Olin niin loukkaantunut häneen, että sitä en unohda koskaan...koin, että hän ei ollut äitini - että hän ei välittänyt meistä lainkaan.

Yllä oleva esimerkki kuvaa tyypillistä risteytyväksi koettua kommunikaatiota. Kertoja kokee että häntä ei ole ymmärretty. Äiti ei reagoi odotetusti huolehtivana ja lohduttavana Vanhemman minän tilassa, vaan torjuu lapsen tarpeen tulla ymmärretyksi ja hoivatuksi. Esimerkin voi tulkita niin, että äiti toimii Lapsen egotilassa vetäytyessään tilanteesta.

\section{Tavoitteena autonomisesti toimivien perheenjäsenten kehittyminen}

Kuvittelemme itsemme autonomisiksi eli Aikuisen minän tilassa toimiviksi, mutta kuitenkin meitä voi luonnehtia tietyn käsikirjoituksen mukaan tunteviksi, toimiviksi ja ajatteleviksi (James 1977, 3). Autonominen on henkilö, joka toimii oma-aloitteisesti, järkevästi ja luotettavasti niin, että huomioi toisia henkilöitä riittävästi omassa toiminnassaan.
Hän on riippumaton, välitön ja läheisyyteen kykenevä. Hän arvioi, mitä vanhempien opetuksia noudattaa ja kykenee vapaasti ohjaamaan omaa käyttäytymistään. Hän irtautuu vihatta vanhemmistaan (ja muista vanhemman roolissa toimivista) niin, että edelleen seurustelee heidän kanssaan, mutta ei salli heidän vallita omaa mieltään. (Berne 1981, 194 199).

Perhesuhteiden kehittymisen kannalta on tavoiteltavaa, että jokainen perheenjäsen toimii autonomisena eli Aikuisen minän tilassa toimivana, jolloin perheenjäsenet ottavat huomioon esimerkiksi vanhenevien vanhempien tarpeet. Läheisyyteen kykeneminen edesauttaa halua huolehtia perheenjäsenistä.

Perhesuhteet eivät kuitenkaan aina täytä autonomisten ihmisten toiminnan kriteerejä. Alla olevassa esimerkissä ei vihatta ole irtauduttu isästä eikä pidetä yhteyttä hänen kanssaan:

Olen alusta alkaen päättänyt, että jos joku ihminen on halpamainen minua kohtaan, asetan hänet hyllylle, ja siellä hän voi istua ikuisesti. Huxley sanoo, että on oikeus ottaa etäisyyttä kaikista, jotka aiheuttavat pahoja ajatuksia itselle. Ei tarvitse olla tekemisissä sellaisten kanssa, olipa kyseessä sitten oma isä tai sisarukset tai kuka tahansa.

Autonomiseksi toimijaksi tuleminen edellyttää usein, että ihmiset pohtivat toimintaansa ja tulkintaperusteitaan suhteessa perheenjäseniinsä lapsuudesta nykyhetkeen (ks. James 1977, 4). Pettymysten ja kriisien käsitteleminen ja niiden ratkaisuista neuvotteleminen tulee keskeiseksi, jotta perheen jäsenet voivat ylläpitää ja kehittää vastavuoroisia huolenpitosuhteita. (King \& Wynne 2004, 11-12). Tämä edellyttää, että molemmat osapuolet ovat valmiita neuvottelemaan. Tämä valmius voi jäädä yksipuoliseksi:

Minulla ei ollut syyllisyyden tunnetta, siksi saatoin vihata häntä. Ja siksi en halunnut olla hänen kanssaan tekemisissä. Mutta hän kyllä piti minusta. Heti kun hän pelkäsi tai oli jotakin, hän tuli minun luokseni ja pyysi apua silloin aikuisena... Myös silloin, kun emme enää olleet tekemisissä toistemme kanssa hän tuli firmaan ja sanoi, että hänellä oli ikävä minua. "Niin on todella syytä olla ikävä, kun olet mennyt naimisiin sellaisen puliakan kanssa, että pysyttele nyt hänessä.”

Voimme aktiivisesti ottaa tehtäväksi nykyhetken biografisen käsikirjoituksen muuttamisen suhteessamme perheenjäseniin. Minä -analyysis- 
sa voimme tutkia missä minän tilassa perheenjäsenet toimivat ja missä itse toimimme erilaisissa tilanteissa. Millaisia Lapsen tunteita eri perheenjäsenet herättävät; millaisia Vanhempien asenteita voi omassa toiminnassa nähdä suhteessa muihin perheenjäseniin? Esitetään kysymyksiä eri minän tiloille: Mitä kukin vanhemmista sanoisi/tekisi/ tuntisi? (Vanhemman minän tila); Mitä tiedän asiasta ja mitä tietoja minun tulee hankkia (Aikuisen minän tila)? Mitkä ovat sensuroimattomat tunteeni tässä asiassa (Lapsen minän tila)? (ks. James 1977,40, 62).

Myönteisten perhesuhteiden kehittäminen voidaan jakaa seuraaviin vaiheisiin: 1) tutustutaan omiin minän tiloihin; 2) tehdään näkyväksi kielteiset tunteet ja niiden kasautuminen sekä kerätään aktiivisesti myönteisiä tunteita; 3) nähdään samanlaisuuksia ja eroja perheenjäsenten (myös isovanhempien) käyttäytymisessä ja tunteissa; 4) tullaan tietoisiksi kielteisen käyttäytymisen syistä ja opitaan anteeksiantavaksi; 5) tehdään sopimuksia siitä, miten perheenjäsenten välisiä suhteita kehitetään. (James 1977, 530, 531). Näillä keinoin voidaan luoda aiempaa myönteisempää ja ymmärtävämpää biografiaa omasta itsestä suhteessa omiin perheenjäseniin. Aktiivisen biografisen työskentelyn avulla voi oppia keräämään aktiivisia muistikuvia perheenjäsenistä elämän eri vaiheista. Perheenjäsenten välisissä suhteissa keskeiseksi tulee halu muuttua ja halu ylläpitää vuorovaikutusta. Myönteisempi kokonaiskuva perheenjäsenistä ja neuvottelu perheen ihmissuhteissa voi lisätä halua ylläpitää yhteyksiä perheen jäseniin. Tällöin voi myös halu huolehtia perheenjäsenistä kasvaa.( ks. Jones 2006).

\section{Huolenpito ja vastuu biografian ja tran- saktioanalyysin näkökulmasta}

Perheenjäsenistä huolehtiminen on selkeästi vanhempien vastuulla lasten ollessa pieniä. Vanhempien kasvatustehtävänä on huolehtia lastensa perushoidosta ja psyykkisestä hyvinvoinnista. Lapsia tulee tukea kasvamaan autonomisiksi itsestään ja toisista vastuussa oleviksi perheen- ja yhteiskunnan jäseniksi. ( ks. Suomen laki 1983/683, $1 \S$ ). Perheen lasten ollessa pieniä vuorovaikutusta määrittää vuorovaikutussuhteen epäsymmetria, jolloin vanhempi sukupolvi on ensisijainen vastuunkantaja. Tällöin vanhemmat toimivat suhteessa lapsiinsa korostuneesti Vanhempi - Lapsi ja
Aikuinen - Lapsi minän tiloissa.

Myönteiset muistot vanhempien huolenpidosta lapsuudessa auttavat luomaan myönteistä biografista kuvausta elämästä. Vanhempien lapsuudenaikaista myönteistä huolenpitoa koskeva kerronta voi jäädä niukaksi, kun kerrontahetken biografinen kuvaus on negatiivinen:

Eivät he huolehtineet meistä, paitsi silloin kun me olimme sairaita. Silloin he olivat tavattoman säikähtäneitä.... Silloin he huolehtivat meistä. Isä toi kukan, äiti juoksi edestakaisin ja lääkäri kävi katsomassa joka päivä...

Äiti huolehti vaatteista ja siitä, että saimme hyvää ruokaa ja kaikkea sellaista, mutta kotiapulaiset laittoivat ruoan, pesivät meidät.

Haastattelija: Isän ja äidin kanssa ei erityisesti ollut turvallisuudentunnetta?

$E i$, turvallisuudentunne meillä oli ensimmäisen lastenhoitajan kanssa. Häntä rakastimme ja hänen kanssaan olimme joka paikassa. Mutta ei äidin ja isän kanssa.

Vanhempien vastuuseen liittyy keskeisenä myös, että lapsille opetetaan, että teoilla on seurauksia ja että lapset ovat vastuussa teoistaan. Toisin sanoen ohjataan lapsia toimimaan tekojensa suhteen Aikuisen minän tilassa. Tämä vastuu omista teoista voi lapsuudessa ja nuoruudessa jäädä selkiytymättä, niin että edelleen vanhuudessa elämää tarkasteltaessa voidaan nähdä tilanne Lapsen minän tilasta:

Kun saimme selkään niin emme olleet mitään tehneet. Se johtui isän huonosta tuulesta. Ei se meistä riippunut. Me emme koskaan tienneet, miksi saimme selkään.... Minun piti kuulustella veljeni läksyjä, koska hän oli niin mahdoton koulussa. Olin silloin noin 13-14 -vuotias. Kun istuimme siinä ja kuulustelin häntä, niin ilkeä pikkusiskoni tulee ja matkii kaikkea mitä sanomme. Ja silloin en voinut jatkaa sitä ja sanoin, että hänen (pikkusiskon) on mentävä huoneeseensa. Ja niin vedin hänet jaloista alas sohvalta ja hän löi vähän päänsä sohvaan tai lattiaan, en tiedä. Ja niin panin hänet huoneeseensa ja lukitsin oven. Ja hän seisoi oven takana ja itki "bää, bää” ja tämän isä kuuli. Hän oli kauhealla tuulella ja tuli sisään nähdäkseen, voisiko hän saada käsiinsä jonkun jolle antaa selkään. Sitten hän valitsi minut... ja sitten hän avasi oven ja sanoi pikkusiskolleni: "Mitä hän on oikein tehnyt?”. ”Hän veti minua jaloista niin että löin 
pääni.” Ja hän (isä) ilahtui suuresti siitä, että sai antaa selkään.

Vanhuuden kerronnassa pikkusisko jää "ilkeäksi" ja oma toiminta nuhteettomaksi, eli kertoja toimii Lapsen minän tilassa. Kerronnassa ei kyetä Aikuisen minän tilassa tarkastelemaan eri osapuolten vastuuta tapahtumasarjassa, jolloin voisi ymmärtää laajemmin omaa, sisarusten ja isän toimintaa. (ks. Berne 1964, 158-161).

Perheen jäsenten välinen elinikäinen vastavuoroinen huolenpidon kehittyminen vaatii jatkuvaa neuvottelua. Tämä edellyttää eri minän tilojen vaihtelua ja muuttumista kohti suurempaa Aikuisen minän tilan osuutta elämässä. Perheen muuttuessa, kun lapset kasvavat ja vanhenevat, neuvotellaan uudelleen lapsi-vanhempisuhdetta. Tätä neuvottelua käydään kussakin elämänvaiheessa yhä uudelleen. Suhteen tulisi muuttua kohti tasaarvoista Aikuinen - Aikuinen transaktiota ja kohti vastavuoroisia huolenpitosuhteita. (ks. Lucchetti \& Powers, Love 2002). Kielteisissä tapauksissa perheen jäsenet eivät kykene muuttamaan roolejaan ja seurauksena voi olla, että perheenjäsenet eristäytyvät toisistaan ja suhteista muodostuu vihamielisiä ja kriittisiä (King \& Wynne 2004, 10). Tällöin esimerkiksi vanhemmat eivät kykene luopumaan Vanhempi - Lapsi transaktioista. Tästä osuva esimerkki on aiempi kuvaus kertojan äidin kuolinvuoteelta, jossa edelleen viestittiin lapsuudenaikaista ehdottoman tottelemisen vaatimusta.

Sukupolvien välisen vuorovaikutuksen aivan viimeisinä vuosina vuorovaikutus hoivasuhteessa voi kääntyä epäsymmetriseksi, jolloin edellytetään nuoremman sukupolven korostunutta vastuullisuutta (ks. Cohen 2005; Epstein 1995). Tällöin vanhempi on enenevästi Lapsen minä tilassa ja lapsen tulee kyetä toimimaan Aikuisen minän tilassa:

...äidistä tuli vihainen minua kohtaan. Hän ei suonut minulle mitään... En tiedä miksi. Hänen päältään näki heti, että hän oli kiukkuinen ja oli parasta olla puhumatta hänelle... Hänellä (äidillä) oli 10 onnellista vuotta, kun hän rupesi elämään täällä (kertojan kanssa).... Kaikki oli hyvin (äidin ja kertojan välisessä suhteessa), kunnes hän täytti 83 vuotta. ...Hänestä tuli epäluuloinen kaikkia kohtaan. Epäluuloinen, että hänelle tahdottiin pahaa, että hänestä puhuttiin pahaa... Kummallinen epäluuloisuus.
Huolenpito ja vastuu toisesta nähdään vaiheittain kehittyvänä prosessina (Gilligan 1982, 74). Ensin keskitytään omien etujen turvaamiseen ja oman onnellisuuden takaamiseen. Tämä ymmärretään kuitenkin kehityksen seuraavassa vaiheessa itsekkyydeksi. Tällöin huolenpito ja vastuunotto toisesta lisääntyvät, vaikka oma etu on edelleen keskeinen. Tätä seuraavassa kehitysvaiheessa toisesta huolehtiminen ja vastuu toisesta ohittaa omat tarpeet. Itsensä unohtaminen muista huolehdittaessa johtaa kuitenkin kriisiin. Tällöin itseä kuormitetaan enemmän kuin jaksetaan. Viimeisenä huolenpidon kehitysvaiheena on, että itsestä ja muista huolehditaan vastavuoroisesti. Tällainen vastavuoroisuuden periaate edellyttää tasapainoa itsestä ja muista huolehtimisessa. (ks. Gilligan 1982, 74; Juujärvi 2004, 105-107; Pratt, Skoe; Arnold 2004).

Itsekkäässä vaiheessa transaktioissa toimitaan korostuneesti Lapsen minän tilassa, jolloin ensisijaista huolenpitosuhteessa on oman hyvänolon tunteen tai edun takaaminen. Tästä on esimerkkinä kuvaus kertojan äidin vanhuusvaiheesta, jolloin kertoja oli ottanut äitinsä hoidettavakseen. Kertoja järjesti itselleen omaisuutta äidistään huolehtiessaan:

Tajusin millaiset sisarukseni ovat ja että minua on kohdeltu epäoikeudenmukaisesti. Silloin päätin huolehtia siitä, että minulla on vanhuus turvattuna (taloudellisesti). ...Aina se henkilö joka... elää toisen henkilön kanssa, voi järjestää (omaisuutta) itselleen.

Itsensä unohtavassa vaiheessa taas toimitaan Vanhemman minän tilassa. Itseä rasitetaan kohtuuttomasti. Korostuneessa Vanhemman minän tilassa toimitaan "pelastajana” ja itse asiassa estetään huolehtimisen kohteena olevaa toimimasta Aikuisen minän tilassa (ks. Burgess 2005,100):

Minä huolehdin hänestä... ja palvelin häntä ja huolehdin koko taloudesta. ...

Äiti ei ollut tottunut tekemään mitään. Hän oli tottunut siihen, että häntä palveltiin. En pysty kuvittelemaan häntä lattiaa lakaisemassa, ikkunaa pesemässä, en koskaan.

Kun on vastuussa toisesta ihmisestä (äidistä) ja tahtoo huolehtia siitä, että hän pystyy elämään säädyn mukaisesti, että toinen ei huomaa, että rahaa ei ole, silloin tuntee olonsa samanlaiseksi kuin miespuolinen elättäjä. Todella epämiellyttävää.

Kun kehitytään vastavuoroisesti itsestä ja muista 
huolehtivaksi ja vastuuta kantavaksi, toimitaan enenevästi Aikuisen tilassa. Ymmärretään, että myös omasta jaksamisesta on huolehdittava. Sisarukset voivat yhdessä neuvotellen ja Aikuisen minän tilassa toimien jakaa vanhempien hoidon taakkaa ja huolehtia vastavuoroisesti myös toinen toisensa jaksamisesta mahdollistamalla muita ihmissuhteita ja hoitotaukoja.

Vastavuoroisuus hoitosuhteessa vanhoihin vanhempiin edellyttää tasapainoa vanhemmista ja omasta itsestä huolehtimisessa. Tämän tasapainon voi olettaa edesauttavan hoidon laatua ja jaksamista vaikeissakin hoitosuhteissa. Tasavertainen vastavuoroinen huolenpitosuhde estyy, mikäli hoitosuhteessa toimitaan kommunikaatiossa pääsääntöisesti Vanhempi - Lapsi minän tiloissa. Esimerkkimme biografiassa hoitosuhteen ehdoksi asetettiin, että äiti ei saanut tavata muita lapsiaan:

Hän (äiti) sai sopeutua siihen (että veli ja isä eivät saa käydä). Hän (äiti) olisi kyllä edestakaisin (sallinut/ei sallinut suhteita), mutta minä sanoin, että se ei käy. "Sen vuoksi en ole sinua luokseni ottanut."

Hoitosuhde oli kuitenkin pitkä, yli 10 vuotta, ja se muodostui loppuvaiheessa monella tavalla raskaaksi:

60-vuotiaana hoidin äitiä. Valtavan raskasta. Minulla ei ollut ketään, joka olisi tuurannut kanssani. Yritys meni konkurssiin, koska olin koko ajan sairaalassa.

...eristäydyin muista ihmisistä. ... Huolehdin äidistä....Hän oli hyvin vaativa. En saanut koskaan mennä ulos iltaisin. En myöskään saanut pitää vieraita. Hän ei pitänyt siitä.

Kertoja esti sisarusten ja sisarusten lasten yhteydenpidot hoidettavaan äitiin ja äiti vastavuoroisesti rajoitti kertojan ihmissuhteita ja hoitotaukojen ottamista. Loppuvaiheessa huolenpitosuhteesta tuli kohtuuttoman rankka, kun mahdollisuuksia itsestä huolehtimiseen ja hoitovastuun jakamiseen ei ollut.

\section{Lopuksi}

Yhteiskunta tullee enenevästi odottamaan omaisten ottavan vastuuta vanhoista vanhemmista ja muista sukulaisista, kun vanhojen ihmisten osuus väestöstä kasvaa ja taloudelliset resurssit ovat niukat. Tällöin vastavuoroisen tasavertaisen huolenpitosuhteen kehittäminen tulee tärkeäksi. Sisarukset ja heidän väliset suhteensa sekä suhteet vanhempiin tulevat avainasemaan.

Artikkelini tavoitteena on tarjota työvälineet (biografinen työskentely ja transaktioanalyysi) muutoksille. Tässä haastetaan perheenjäseniä reflektoimaan ja rakentamaan omaa biografiaa myönteisemmäksi. Oman vastuun näkeminen perheen ihmissuhteista voi toimia herätteenä muutokselle.

Artikkelissa käytetty biografinen esimerkki on kerronnaltaan hyvin negatiivinen. Tämä ei välttämättä ole huono asia, koska tällöin ongelmakohdat näkyvät kärjistyneen selvästi. On ehkä turvallisempaa tarkastella oman elämän ongelmakohtia, kun joko ei ole ainoa, jolla on ollut hankala elämä tai, kun ei sentään ole ollut ihan noin hankalaa.

Biografian perusominaisuutta eli sitä, että nykytilanteesta tarkastellaan mennyttä elämää ja menneen elämän ihmissuhteita, voi aktiivisesti käyttää hyväksi. Omaa tämänhetkistä näkemystä perheestä voi aktiivisesti työstää myönteisemmäksi rakentamalla ymmärtämystä koko elämän aikaisista kokemuksista. Hyviä kokemuksia voi poimia näkyviin ja yrittää ymmärtää kunkin henkilön toimintaa heidän elämänkulkunsa näkökulmasta.

Hyvien suhteiden luominen perheenjäsenten välille edellyttää vanhemmilta sisarusten tasapuolista kohtelua ja aktiivista hyvien sisarussuhteiden rakentamista. Ennen vanhempien vanhuuden huonokuntoisuuden vuosia on keskeistä ylläpitää perheenjäsenten välisiä säännöllisiä tapaamisia, jotta halu huolenpitoon olisi luontevaa. Näissä tapaamisissa neuvotellaan yhä uudelleen perheenjäsenten välisiä suhteita ja biografisia kokemuksia.

Aikuiset perheenjäsenet voivat transaktioanalyysin $^{5}$ minä-analyysien avulla tarkastella missä minän tiloissa he toimivat eri tilanteissa. Tällöin voi myös analysoida vuorovaikutusrakenteiden muotoa ja tehdä risteytyvät transaktiot näkyviksi. Tällainen toiminta voi parantaa perheenjäsenten välisiä vuorovaikutussuhteita, jolloin myös halu toisesta huolehtimiseen voi kasvaa. Vuorovaikutuksen tavoitteeksi voi asettaa autonomisten psykologisesti tasa-arvoisten täydentyvien transaktioiden rakentamisen erityisesti ennen vanhempien myöhäisvanhuutta.

Myöhäisvanhuudessa olevien vanhempien hoivasuhteessa huolenpitäjän jaksamisen ehtona voi pitää, että huolenpitosuhde rakentuu tasapainolle itsestä huolehtimisen ja vanhemmista huolehtimisen välillä. Tämä edellyttää mahdolli- 
suuksia irrottautua hoivasuhteesta säännöllisin väliajoin. Tässä toimivat ja hyvät sisarussuhteet ovat avainasemassa.

Perheenjäsenten keskinäisten suhteiden kehittäminen ei kuitenkaan voi korvata niitä yhteiskuntapoliittisia päätöksiä, joita vanhustenhuolto edellyttää. Miten työssäkäyvät omaiset saavat aikaa ja taloudellisia mahdollisuuksia vanhusten hoitoon? Miten hoidetaan hoitamaan jääneen omaisen eläketulojen kertyminen?

Lopuksi viittaan Kansallisen sosiaalialan kehittämisprojektin osaan 2, jossa käsitellään vanhusten huoltoa ja siinä esitettyä toimenpide-ehdotusta 10:

"Omaishoitajien asemaa tulee parantaa pitkäjänteisillä ratkaisuilla ja tuki- ja lomapalveluita kehittämällä. Tästä erikseen selvityshenkilöt esittävät, että kolmikantayhteistyön puitteissa valmisteltaisiin lainsäädäntöä, jossa työntekijälle säädeltäisiin oikeus lyhytaikaisesti jäädä pois työstä oman vanhemman hoidon järjestämiseksi ennakoimattomassa tilanteessa, siirtyä pitempiaikaisesti lyhennetylle työajalle oman vanhemman hoitoon osallistumiseksi ja jäädä määräajaksi pois työstä oman vanhemman hoidon terminaalivaiheessa. Tämän oikeuden laajentaminen koskemaan myös muita lähiomaisia on tarpeen selvittää. Tämä merkitsee nykyisen työsopimuslain 4 luvun 7 §: n säännösten oleellista laajentamista.” (http:// pre20031103.stm.fi/suomi/pao/kehittämisprojekti/ osa2.htm/ 26.7.2007

Toimenpide-ehdotus kuvaa sitä, miten aikaa olisi mahdollista järjestää omaishoitoon. Tämä ehdotus on vasta prosessin ensimmäinen vaihe, joka sinänsä edellyttää taloudellisesti merkittäviä ratkaisuja. Ratkaistavaksi jäävät kuitenkin esimerkiksi omaishoitajan mahdolliset menetettyyn eläkekertymään ja palkkaukseen liittyvät taloudelliset kysymykset. Perhepoliittiset kysymykset siis odottavat yhteiskunnallista arvokeskustelua ja poliittista päätöksentekoa.

\section{Lähteet}

Berne, E. (1964/1967). Games people play. The psychology of human relationships. Harmondsworth: Penguin Books, Ltd.

Berne, E. (1981). Kanssakäymisen kuviot. Ihmissuhteiden psykologiaa. Helsinki: Gummerus.

Burgess, R.C. (2005). A model for enhancing individual and organisational learning of 'emo- tional intelligence': The drama and winner's triangles. Social Work Education, Vol. 24 (1), 97-112.

Cohen, H.L. (2005). Sisters and brothers/daughters and sons: Meeting the needs of older parents. Journal of Women and Aging, Vol. 17 (1-2), 188-190.

Denzin, N.K. (1989). Interpretative biography. Qualitative research methods series 17. Sage university paper.

Eriksson-Stjernberg, I. (1998). Emotions in lifelong learning. A biographical perspective. Nordisk Pedagogik, Vol. 18, 65-75.

Epstein, S.N. (1995). Parental caregiving by adult children: Perceptions of roles and sibling interactions. Dissertation Abstracts International: Section B: The Science and Engineering. 2005 (55), (8-B), 3636.

Gilligan, C. (1982). In a Different Voice. Cambridge: Harvard University Press.

James, J. (1977). Family therapy with TA. Teoksessa James, M. ja avustajat. Techniques in transactional analysis for psychotherapists and counselors. Reading: Addison-Wesley Publishing Company, 351-371.

James, M. (1977). Principles of TA. Teoksessa James, $\mathrm{M}$ ja avustajat. Techniques in transactional analysis for psycyhotherapists and counselors. Reading: Addison-Wesley Publishing Company, 3-18.

James, M. (1977). Self reparenting: theory and process. Teoksessa James, $\mathrm{M}$ ja avustajat. Techniques in transactional analysis for psycyhotherapists and counselors. AddisonWesley Publishing Company, 486-496.

Jones, K. (2006). Informal care as relationships: the case of the magnificent seven. Journal of Psychiatric and Mental Health Nursing. Vol. 13, 214-220.

Juujärvi, S. (2004). Huolenpidon etiikan kehitys. Lectio praecursoria. Psykologia Vsk. 39 (02), 105-109.

Kansallinen sosiaalialan kehittämisprojekti. STM. Työryhmämuistioita (2003):11. http:// pre20031103.stm.fi/suomi/pao/kehittamisprojekti/osa2.htm

Killian, T., Ganong, L.H. (2002). Ideology, context, and obligations to assist older persons. Journal of Marriage and Family, Vol. 64 (4), 
1080-1088.

King, D.A., Wynne, L.C. (2004). The emergence of "family integrity" in later life. Family Process, Vol. 43 (1), 7-21.

\section{Lastensuojelulaki 1983/683}

Lucchetti, A.E., Powers, W.G., Love, D.E. (2002). The empirical development of the child-parent communication apprehension scale for use with young adults. The Journal of Family Communication, Vol. 2 (3), 109-131.

Pratt, M.W., Skoe, E.E., Arnold, M.L. (2004). Care reasoning development and family socialization patterns in later adolescence: A longitudinal analysis. International Journal of Behavioral Development, Vol. 28 (2), 139-17.

Tilastokeskus 2007. http://www.stat.fi/tup/suoluk/suoluk_vaesto.html (luettu 18.10.2007)

\section{Viitteet}

1. Suomen lain mukaan vanhemmilla on huolenpito- ja elatusvastuu lapsistaan 18-ikävuoteen asti (Laki 1983/683).

2. Transaktioanalyysia on viime vuosina käytetty mm. sosiaalitoimen, terveydenhuollon ja kasvatuksen kentillä vahvistamaan vastuunottoa sosiaali- sessa vuorovaikutuksessa (Burgess 2005).

3. Avoimia haastatteluja tein 32 tuntia. Litteroituna tekstiä oli 153 sivua ykkösrivivälillä.

4. Täydentyvän ja risteytyvän transaktion lisäksi keskeinen vuorovaikutuksen muoto on piiloinen vuorovaikutus, joka kuvaa sanojen ohella lähetettyjä emotionaalisia viestejä. Nämä emotionaaliset viestit voivat olla täydentyviä tai risteytyviä, jolloin vuorovaikutus itse asiassa on huomattavan monimuotoista. Tässä artikkelissa ei kuitenkaan tarkastella piiloista vuorovaikutusta, koska ei tarkastella aitoa vuorovaikutusta, vaan kerrottuna tulkittua vuorovaikutusta. (ks. James ja avustajat 1977, 12-14)

5. Transaktioanalyysi on tietenkin psykoterapeuttisena muotona erittäin monimutkainen analyysimuoto, mutta karkeana työvälineenäkin se voi avata perheenjäsenten silmiä näkemään omaa vuorovaikutusta itselleen uudella tavalla. 